\title{
Menguak Konsep Pendidikan Eko-Religius KH. MA. Sahal Mahfudh
}

\author{
Sholahuddin \\ Fakultas Ekonomi dan Bisnis UNISNU \\ sholahuddinmuhsin01@gmail.com
}

\begin{abstract}
Riwayat Jurnal
Artikel diterima: 9 April 2019

Artikel direvisi: 3 Mei 2019

Artikel disetujui: 24 Juni 2019
\end{abstract}

\begin{tabular}{|l|l|}
\hline Kata Kunci: & Abstrak \\
Kendidikam Eko religius, & Meningkatnya kerusakan lingkungan hidup merupakan bencana \\
bagi manusia secara umum. Kerusakan lingkungan juga menjadi \\
sorotan oleh KH Sahal Mahfudh, seorang ulama' kharismatik \\
dari Pati Jawa Tengah. Beliau menganggap bahwa manusia \\
adalah makhluq yang paling bertanggungjawab atas kerusakan \\
lingkungan. Penelitian ini menguak konsepsi pendidikan \\
lingkungan hidup yang ditelurkan oleh KH Sahal Mahfudh. \\
Dengan metodologi penelitian kualitatif dan melakukan \\
penelitian dengan teknik interview dan observasi penelitian ini \\
berhasil mengungkapkan bahwa Kiai sahal memiliki konsepsi \\
pendidikan lingkungan hidup yang perlu untuk digali lebih \\
mendalam lagi. Konsepsi tersebut berdasarkan bahwa tujuan \\
hidup manusia adalah sa'adah fid daroin (kebahagiaan didunia \\
dan akherat), untuk menuju kesana, manusia perlu menjaga \\
lingkungan sebagai masis dari kehidupan mereka.
\end{tabular}




\begin{tabular}{|l|l|}
\hline & are then contextualized according era. Ultimately, ecological \\
education will bring Muslims become Sholih-akram, which is the \\
highest degree of taqwa and most good in maintaining social \\
relationships, managing nature, and conserve the environment. \\
This research is a study of character with the historical- \\
philosophical approach, trying to figure radically probing, \\
comprehensive, and contextual. The collection of data with the \\
documentation (paper figures and works of figures) and \\
interviewing the structure of the party once associated with the \\
character. The data is then analyzed using content analysis (the \\
idea of a character in the works) and interpretive analysis, the \\
associate messages and thoughts with the socio-cultural \\
conditions in the present context. The finding of this research is \\
that is concept of education for preserving environment \\
according to Kiai Sahal Mahfudh.
\end{tabular}

\section{Pendahuluan}

Manusia dan alam merupakan kesatuan dalam ekosistem yang saling mempengaruhi satu dengan lainnya. Manusia -termasuk hewan dan tumbuhan sebagai komponen biotikhidup dari dan sekaligus berdampingan dengan alam dari unsur abiotik (benda tak hidup seperti air, tanah, udara). Manusia menggantungkan hidupnya dari sumber daya alam yang ada, sementara alam memberikan apa yang dibutuhkan manusia. Kondisi lingkungan yang berbeda-beda menghasilkan cara adaptasi yang berbeda pula dari manusia.Kelangsungan hidup manusia tergantung pada kemampuannya untuk menyesuaikan diri dengan lingkungan hidupnya. Apabila terjadi perubahan pada lingkungan hidup yang berada di luar batas adaptasi manusia, maka kelangsungan hidup manusia akan terancam. Saat ini, hubungan manusia dan alam berjalan tidak sehat sehingga menimbulkan situasi yang mengkhawatirkan, yakni "krisis lingkungan”. (Maizer Said dan Aziz Ghufron, 2003, p, 196) Krisis lingkungan berakibat pada kerusakan lingkungan hidup, dan kerusakan tersebut berimbas pada kelangsungan hidup manusia itu sendiri.

Eksploitasi sumber daya alam telah mengakibatkan bumi semakin tertekan untuk terus melayani lingkungan dan kehidupan yang bermartabat dan berkelanjutan bagi penghuninya. Perlu disadari, bahwa bumi tak hanya mempunyai daya dukung yang terbatas, tetapi juga terus menyusut, sedangkan tekanan justru terus membesar. Krisis lingkungan dan kerusakan alam terjadi pula di Indonesia dengan berbagai fakta yang mengerikan.Berdasarkan data terakhir dari Kementerian Lingkungan Hidup Indonesia, pada 2012 sudah ada 300 kasus kerusakan lingkungan hidup seperti kebakaran hutan, pencemaran lingkungan, pelanggaran hukum, dan pertambangan. Data lain yang mendukung tentang potret lingkungan Indonesia 
adalah berdasarkan Indeks Kualitas Lingkungan Hidup yang dibuat oleh Kementerian Lingkungan Hidup. Tercatat, ada penurunan kualitas lingkungan, yakni pada 2009 sebesar 59,79\%, 2010 sebesar 61,7\%, dan 2011sebesar 60,84\%. Hal ini diperkuat dengan data terakhir Menuju Indonesia Hijau di mana Indonesia hanya memiliki luas tutupan hutan sebesar $48,7 \%$ seluruh Indonesia.

Menurut UU No. 32 tahun 2009 tentang perlindungan dan pengelolaan lingkungan hidup, yang dimaksud dengan lingkungan hidup adalah kesatuan ruang dengan semua benda, daya, keadaan dan makhluk hidup termasuk manusia dan perilakunya, yang mempengaruhi alam itu sendiri, kelangsungan perikehidupan, dan kesejahteraan manusia serta makhluk hidup lain. Definisi tersebut menyebutkan bahwa manusia dan perilakunya sangat berpengaruh terhadap kelangsungan lingkungan hidup.Keinginan manusia untuk dapat hidup selaras dengan lingkungan dan alam masih sulit diwujudkan karena tiga hal. (Abdul Karim, 2012, P; 4) Pertama, kebutuhan yang bersifat materiil menjadi pilihan utama, imbasnya pada rendahnya kepedulian terhadap aspek lain seperti lingkungan dan budaya. Kedua, perebutan lahan usaha yang terbatas tanpa adanya kemauan mencari peluang lain. Ketiga, longgarnya pegangan terhadap nilai-nilai agama serta menonjolkan ilmu pengetahuan dan teknologi. Sikap ini dianggap bisa mengancam kondisi lingkungan hidup.

Sikap dan perilaku yang mengarah pada kerusakan lingkungan hidup menunjukkan kondisi masyarakat yang kacau. Maka ajaran Islam hadir untuk melakukan perbaikan akhlak manusia agar tidak menyimpang. Salah satu bentuk perbaikan yang dilakukan Allah adalah dengan mengutus para Nabi dan Rasul untuk meluruskan dan memperbaiki kehidupan yang kacau dalam masyarakat. Siapa yang tidak menyambut kedatangan Rasul, atau menghambat misi mereka, dia telah melakukan salah satu bentuk perusakan di bumi. (M. Quraish Shihab, P: 144) Disadari atau tidak, setiap hari manusia banyak melakukan hal-hal yang berpotensi merusak alam dan lingkungan sekitar.Misalnya terkait dengan air, manusia setiap hari -baik dari industri, rumah tangga, atau sebagai individu- menggunakan air sebagai kebutuhan sehari-hari. Hampir semua aktivitas manusia memerlukan air, seperti untuk mandi, mencuci, minum, atau membersihkan lantai. Menurut data yang dilansir WHO, bahwa setiap orang di Negara maju memerlukan 60-120 liter air setiap hari. Sementara di Negara berkembang termasuk Indonesia- setiap orang menghabiskan antara 30-60 liter perhari. (Soekidjo Notoatmodjo, 2007 P; 173)

Apabila diasumsikan penduduk Indonesia sekitar 250 juta jiwa, maka setiap hari masyarakat Indonesia menghabiskan air 7.500-15.000 juta liter. Dari sekian banyak yang 
dipakai, $80 \%$ di antaranya terbuang sia-sia karena hanya sekitar 20\% saja yang benar-benar dipakai. Untuk mandi misalnya, paling banyak hanya $10 \%$ air yang benar-benar membersihkan badan, sedangkan sisanya hanya lewat dan terbuang percuma.Sayangnya, tingkat konsumsi air yang tinggi tersebut tidak dibarengi dengan kemampuan untuk mengelola air dengan bijak. Contoh nyata terjadi di Indonesia, negeri yang hanya mempunyai dua musim dalam satu tahun (penghujan dan kemarau) terlihat tidak memilliki kemampuan untuk mengelola air dengan bijak. Ketika musim penghujan di mana debit air melimpah, berbagai daerah dilanda kebanjiran, sementara saat musim kemarau datang, masyarakat merasa sangat kebingungan dan kesulitan mencari air bersih.

Dampak dari ketidakmampuan mengelola air yakni timbul bencana seperti banjir, longsor, kekeringan, paceklik, yang pada dasarnya berawal dari kesalahan manusia sendiri dalam mengelola air, bukan dari kesalahan alam. Kesalahan terbesar dari berbagai bencana yang berkaitan dengan air- yakni dalam hal pengelolaan dan pemanfaatan hutan. Hutan dengan beragam varietas yang hidup di dalamnya merupakan "tendon air" alami yang dapat menyerap dan menyimpan air di musim penghujan, sekaligus menyuplai dan menjaga air saat kemarau. Kerusakan dan pengurangan hutan berakibat fatal pada siklus air yang berakibat pada terjadinya bencana.Kerusakan hutan di tanah air cukup memprihatinkan, berdasarkan catatan Kementrian Kehutanan Republik Indonesia, sedikitnya 1,1 juta hektar atau 2\% dari hutan Indonesia menyusut tiap tahunnya. Data Kementerian Kehutanan menyebutkan dari sekitar 130 juta hektar hutan yang tersisa di Indonesia, 42 juta hektar diantaranya sudah habis ditebang. Bahkan Guinness Book Record tahun 2008 mencatat Indonesia sebagai Negara penghancur hutan tercepat di dunia. Pada tahun 1950, 84\% daratan di Indonesia adalah hutan, namun 55 tahun kemudian tepatnya tahun 2005 hanya tersisa 43\% hutan. Dalam satu jam, Indonesia kehilangan hutan seluas 300 lapangan sepakbola. Jadi dapat dikatakan bahwa semakin berkurang luas hutan, semakin besar ancaman bahaya yang mengancam kelangsungan hidup manusia.

Selain kerusakan dan pengurangan luas hutan di Indonesia, permasalahan lingkungan yang lain datang dari sampah, yakni suatu benda atau benda padat yang dihasilkan dari kegiatan manusia -baik langsung atau tidak langsung- yang sudah tidak dipakai. Dini hari pada tanggal 21 Februari tahun 2005 silam, "gunung sampah" di tempat pembuangan akhir (TPA) Leuwigajah di desa Leuwigajah, Cimahi, Jawa Barat longsor. Sebanyak 143 jiwa melayang dan puluhan hektar lahan pertanian terkubur timbunan sampah. Untuk mengingatkan masyarakat akan bahaya sampah, maka hari terjadinya tragedi Leuwigajah 
ditetapkan sebagai Hari (Peduli) Sampah Nasional. Selepas tragedi tersebut, sangat disayangkan ternyata pengelolaan sampah di Indonesia hampir tidak ada perubahan yang signifikan. Pemerintah maupun masyarakat masih berpikir bahwa sampah harus dibuang karena dianggap tidak mempunyai nilai. Setiap saat manusia menghasilkan sampah baru sementara pengelolaannya masih semrawut. Akibatnya, sampah menumpuk di tempat pembuangan akhir (TPA) atau tempat pembuangan sementara (TPS) yang menghasilkan bau tidak sedap serta membuat lingkungan rawan penyakit. Sampah ini mencemari udara, air, dan tanah karena melepas gas karbondioksida $(\mathrm{CO} 2)$ dan metana $(\mathrm{CH} 4)$, serta beberapa bahan kimia yang berbahaya bagi kelangsungan hidup manusia, alam, dan lingkungan.

Di Jakarta, setiap hari sampah yang dihasilkan oleh warganya sekitar 6.700 ton, dengan $65 \%$ berasal dari rumah tangga. Mayoritas sampah yang dihasilkan tersebut langsung dibuang tanpa diadakan verifikasi, mana yang masih bisa dipakai, mana sampah organic, atau anorganik. Kebiasaan mayoritas masyarakat langsung menjadikan satu beragam sampah kemudian dibuang. Akibatnya gunung sampah di TPA semakin tinggi dan berpotensi menyebabkan bencana dan pencemaran. Hal ini sangat berpotensi merusak air, udara, dan tanah. Salah satu sampah "favorit" masyarakat ialah sampah plastik, ketika belanja di manapun -supermarket atau pasar tradisional bahkan pedagang kali lima- penggunaan kantong plastik terus terjadi. Padahal satu kantong plastik membutuhkan waktu setidaknya 500 - 1.000 tahun agar bisa terurai sempurna secara alami. Waktu terurai yang lama ditaKiaipenggunaan yang terus-menerus, maka tidak mengherankan apabila sampah plastik menumpuk dan menyebar di hampir seluruh daerah di Indonesia.

Langkah pemerintah melalui penerbitan Surat Edaran Menteri Lingkungan Hidup dan Kehutanan nomor S.71/MENLHK-II/2015 yang menginstruksikan pemerintah daerah, kota, dan kabupaten, serta produsen dan pelaku usaha untuk melakukan langkah pengurangan sampah. SE tersebut kemudian ditindaklanjuti dengan penetapan kantong plastik berbayar yang sedang diujicobakan. Setiap kantong plastik yang dipakai konsumen dihargai Rp. 200, sebuah harga yang tergolong sangat kecil jika dibandingkan dengan dampak negatif yang dihasilkannya. Meskipun kecil namun langkah tersebut patut untuk diapresiasi dan diikuti oleh masyarakat sehingga kita dapat menekan penggunaan kantong plastik seperti di banyak Negara Eropa. Bagi masyarakat yang peduli lingkungan, tentu akan memilih alternatif lain kertas atau bahan lain- sebagai pengganti plastik.

Meningkatnya kerusakan lingkungan hidup yang terjadi di Indonesia dalam beberapa tahun ini merupakan bencana bagi masa depan bangsa dan umat manusia. Sebut saja bencana 
kabut asap yang terjadi akibat kebakaran hutan dan lahan di Sumatera dan Kalimantan, selain menyebabkan penyakit ISPA (infeksi saluran pernafasan akut) hingga korban jiwa, kebakaran tersebut juga membuat lahan menjadi tidak subur. Atau ancaman banjir yang terjadi di hampir seluruh daerah di Indonesia, serta kekeringan yang melanda wilayah lain dari negeri ini. Contoh nyata bencana berlawanan dalam waktu bersamaan yaitu banjir dan tanah longsor yang terjadi di Sumedang dan Majalengka, Jawa Barat, di saat yang sama Balikpapan mengalami kekeringan dan krisis air bersih sehingga PDAM harus menggilir saluran air ke masyarakat. (Kompas, 16 februari 2016) Menariknya, berita tersebut dimuat di halaman yang sama di Harian Kompas. Fakta itu menunjukkan bahwa anomali cuaca dan ancaman bencana akibat krisis lingkungan terus terjadi di Indonesia.

Ancaman bencana memang bukan milik Indonesia saja, tetapi terjadi di seluruh dunia. Pada tahun 2014, The National Oceanic and Atmospheric Administration (NOAA) mencatat 7 rekor iklim terburuk yang terpecahkan. Terdiri atas: rekor suhu terpanas, peningkatan gas rumah kaca (CO2, $\mathrm{CH} 4, \mathrm{~N} 2 \mathrm{O})$, peningkatan suhu permukaan laut global, peningkatan suhu dalam lautan, peningkatan permukaan laut, pencairan pulau es abadi Pulau Greenland, perluasan kawasan laut es di Antartika. Semua itu merupakan isu global yang harus diantisipasi pula oleh masyarakat.Untuk mengantisipasi krisis lingkungan yang semakin parah, perlu adanya penyadaran kepada masyarakat -baik individu maupun pelaku industrisupaya semakin peduli terhadap lingkungan. Untuk mengatasi permasalahan sosial -dan lingkungan- terkait moral bangsa diperlukan pendekatan yang komprehensif dengan menempatkan pendidikan sebagai ujung tombaknya. Tanpa adanya perhatian yang serius kepada dunia pendidikan, mustahil mengharapkan perubahan pada perilaku bangsa ini.(Darmaningtyas; 2007, P; 41) Maka dari itu, pendidikan lingkungan hidup harus menjadi materi pokok yang diajarkan di berbagai jenjang pendidikan formal, dari usia dini hingga perguruan tinggi. Tentu saja dengan menggunakan strategi dan metode yang disesuaikan dengan perkembangan peserta didik.

Pendidikan lingkungan hidup menjadi sebuah langkah strategis untuk mengembangkan kesadaran ekologis yang mengakui kesatuan, keterkaitan, dan saling ketergantungan antara manusia, tumbuhan, dan hewan di bumi ini. (Sony keraf; 2006, P: 82) lingkungan hidup bertujuan untuk mendorong dan memberikan kesempatan kepada masyarakat memperoleh pengetahuan, memiliki sikap dan keterampilan tentang lingkungan hidup yang pada akhirnya dapat melakukan berbagai hal dalam upaya memanfaatkan dan melestarikan lingkungan hidup secara bijaksana. Dengan demikian, eksploitasi alam secara 
berlebihan tanpa memikirkan kelestariannya dapat ditekan bahkan dihilangkan.Berangkat dari pendidikan tersebut, semakin lama akan tertanam sikap dan perilaku peduli lingkungan hingga dapat meningkatkan kecerdasan ekologis. Kecerdasan ekologis -menurut Golemanadalah kemampuan untuk beradaptasi terhadap ceruk ekologis tempat kita berada. Kecerdasan ekologis membuat manusia dapat menerapkan apa yang dipelajari mengenai akibat aktivitas manusia terhadap ekosistem sehingga dapat mengurangi kerusakan lingkungan. (Daniel Goleman; 2010; p: 37-38) Agar tujuan dan cita-cita tersebut dapat tercapai, dibutuhkan berbagai pendekatan, strategi, dan metode yang sesuai dengan perkembangan dan kondisi sosial masyarakat.

Pendidikan lingkungan hidup sebagai upaya untuk meningkatkan kecerdasan ekologis dapat dilakukan dengan menggunakan pendekatan religiusitas. Religiusitas merupakan inti kualitas hidup manusia dan rasa ingin berada bersama dengan sesuatu yang abstrak (Yang Maha Segalanya). Mengingat masyarakat Indonesia bukanlah kaum ateis, serta semua agama yang diakui Negara mengajarkan kepedulian terhadap alam dan lingkungan. Keterpaduan antara pendidikan lingkungan dengan ajaran agama diharapkan mampu meningkatkan kesadaran masyarakat dalam memelihara dan melestarikan alam.

Islam sebagai agama yang dianut oleh mayoritas penduduk di negeri ini juga sangat peduli terhadap kelestarian lingkungan. Islam, misalnya mengajarkan menjaga kebersihan dan bersuci sebelum melaksanakan ibadah (shalat) serta melarang umat muslim berlebihlebihan, termasuk dalam memanfaatkan sumber daya alam. Kebersihan sebagai syarat dalam beribadah menunjukkan kepedulian yang besar dari agama Islam terhadap masalah lingkungan. Perhatian umat Islam Indonesia terhadap masalah ekologi dapat dilihat dari beberapa keputusan atau gerakan organisasi masyarakat yang berlandaskan Islam. Nahdlatul Ulama (NU) misalnya, dalam Muktamar ke-29 tahun 1994 di Cipasung Tasikmalaya sudah mendorong anggotanya untuk jihad menjaga lingkungan hidup. Salah satu poin penting keputusan muktamar tersebut menyebutkan bahwa pencemaran lingkungan hidup, baik udara, air maupun tanah, apabila menimbulkan dlarar (kerusakan), maka hukumnya haram dan termasuk perbuatan kriminal (jinayat). Sikap tegas ini menunjukkan keseriusan NU dalam menjaga kelestarian alam. Yang terbaru yakni peluncuran gerakan nasional EcoMasjid pada Jumat, 19 Februari 2016 di Masjid Az-Zikra Sentul, Bogor. Gerakan yang diprakarsai oleh Dewan Majid Indonesia, Majelis Ulama Indonesia (MUI), dan Indonesia Begerak Selamatkan Bumi (Siaga Bumi) menjadikan masjid sebagai basis gerakan peduli lingkungan dengan empat program utama, yaitu penghijauan, konservasi air, sanitasi, dan pengelolaan sampah. 
Semua itu merupakan bentuk dari konsep dan aplikasi pendidikan lingkungan hidup berbasis religiusitas. Urgensi pendidikan lingkungan hidup yang juga merupakan bagian dari ajaran agama Islam telah lama disampaikan pula oleh KH. MA. Sahal Mahfudh dalam karyanya "Nuansa Fiqh Sosial". Ulama kharismatik asal Pati yang kerap disapa KiaiSahal ini memang tidak secara eksplisit menjelaskan bagaimana bentuk dan model pendidikan lingkungan hidup berbasis ajaran agama Islam (Eko-Religius). Akan tetapi permasalahan lingkungan hidup banyak dilontarkan dalam berbagai tulisannya. Menurutnya, pembinaan lingkungan hidup dan pelestariannya menjadi amat penting artinya untuk kesejahteraan hidup di dunia dan akhirat. Keseimbangaan dan keserasiannya sangat mempengaruhi dan dipengaruhi oleh sikap rasional manusia yang berorientasi pada kemaslahatan makhluk. (Sahal Mahfudh; 2012, P: 124) Apa yang dilakukan oleh manusia sangat berpengaruh dan dipengaruhi oleh kondisi alam dan lingkungannya. Jelas sekali bahwa manusialah yang bertanggung jawab terhadap apa yang terjadi dengan alam ini.

Hal ini sejalan dengan firman Allah yang berbunyi:

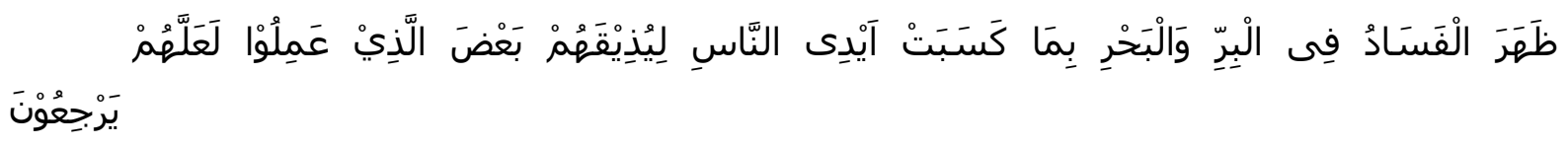

Artinya:

"Telah nampak kerusakan di darat dan di laut disebabkan karena perbuatan tangan manusia, supaya Allah merasakan kepada mereka sebagian dari (akibat) perbuatan mereka, agar mereka kembali (ke jalan yang benar).” (QS: Ar-Rum Ayat: 41)

Allah telah memperingatkan manusia bahwa apabila manusia membuat kerusakan di darat maupun di laut, maka manusia sendiri yang akan merasakan akibat dari perbuatannya tersebut. Hal ini merupakan peringatan supaya manusia menjaga, memanfaatkan, da melestarikan alam dengan baik supaya mendapat akibat yang baik pula. Maka bencana akibat kerusakan lingkungan adalah pengingat supaya manusia kembali ke jalan yang benar (dalam mengelola alam). Salah satu faktor utama eksploitasi alam secara berlebihan dari manusia menurut KiaiSahal- yaitu kemiskinan nilai spiritual sehingga mendorong masyarakat maju memandang alam bukan sebagai sahabat tetapi sebagai sesuatu yang harus ditaklukkan dan dimanfaatkan secara sewenang-wenang. Anggapan inilah yang memicu kerusakan alam dan lingkungan karena ulah tangan manusia sendiri. Pemanfaatan yang berlebihan tanpa dibarengi pelestarian yang optimal jelas akan berakibat pada ketidakseimbangan alam. Tema ekologi atau lingkungan hidup sendiri menjadi bagian dari pemikiran Fiqh Sosial KiaiSahal 
yang komprehensif meliputi berbagai bidang kehidupan. Sayangnya, pembahasan terkait tema ekologis tesebut seakan kurang mendapat perhatian dari para santri dan pembaca jika dibandingkan dengan masalah-masalah sosial atau ekonomi. Tidak hanya kurang, bahkan pemikiran ekologis Kiai Sahal sangat jarang dibahas apalagi dikembangkan oleh para santrinya.

Perlu diketahui bersama bahwa pemikiran ekologis yang dikemukakan KiaiSahal sangat penting bagi kelangsungan hidup manusia karena sejatinya manusia tidak akan dapat hidup dengan nyaman apabila tidak didukung dengan lingkungan alam yang aman dan lestari. Fiqh sosial sebagai bagian dari metodologi memahami realitas dan permasalahan sosial umat berusaha menjamin dan memlihara lima hal pokok, yaitu keselamatan dan kebebasan agama, jiwa, akal, keturunan, dan harta. Keselamatan dan pemeliharaan lima aspek tersebut tidak akan tercapai dengan baik apabila lingkungannya rusak dan kacau. Perhatian terhadap kelestarian alam -kata KiaiSahal- merupakan bagian dari jalan mencapai tujuan utama dalam hidup umat manusia yaitu sa'adatuddarain (bahagia dunia dan akhirat). Agar tujuan tersebut dapat dicapai, manusia harus menjalankan dua fungsi pokok, yaitu ibadatullah (ibadah kepada Allah) agar menjadi insan yang akram (paling bertaqwa), serta menjalankan peran sebagai imaratul ardli (pengelola bumi) untuk menjadi orang yang shalih (dalam konteks lingkungan yakni yang paling baik dalam mengelola alam).

Manusia yang shalih-akram merupakan ciri manusia terbaik yang khas dalam pemikiran KiaiSahal dalam mengajak umat menuju ihsan. Dua hal tersebut - shalih dan akram- adalah kesatuan, bisa dibedakan namun tidak bisa dipisahkan untuk mewujudkan citacita mulia hidup bahagia di dunia dan di akhirat. Yaitu manusia yang memiliki hubungan baik dengan Allah, sesama manusia, dan alam. Berangkat dari urgensi tentang pendidikan lingkungan hidup dan kecerdasan ekologis, ajaran agama Islam dan religiusitas, serta pemikiran kontekstual KiaiSahal yang berdasarkan pada ajaran agama Islam baik dalam alQuran, al-Hadits, maupun dalil-dalil aqliyah. Terdapat titik temu menarik dari pendidikan, agama, dan ilmu lingkungan yang pada akhirnya dapat menaKiaidan mengembangkan teori dan pemahaman terhadap kelestarian lingkungan hidup. Titik temu inilah yang dikemukakan oleh KiaiSahal dalam pemikirannya tentang lingkungan hidup, sebuah pemikiran visioner dari seorang kyai kharismatik dan bersahaja yang patut untuk digali dan dikembangkan. Maka sangat menarik untuk menguak bagaimana konsep pendidikan eko-religius dalam pemikiran KH. MA. Sahal Mahfudh. Sebuah tema yang sangat jarang dibahas oleh penerus KiaiSahal, yakni melihat pendidikan lingkungan hidup dalam perspektif religiusitas (Islam). 


\section{Metode}

Penelitian ini termasuk salah satu jenis penelitian kualitatif dengan menggunakan telaah kepustakaan (library research), yaitu suatu penelitian yang bertujuan untuk mengumpulkan data serta informasi dengan bantuan buku-buku, naskah-naskah, catatancatatan, sejarah tertulis, dokumen, dan materi pustaka lainnya yang terdapat dalam koleksi perpustakaan. Di sini menuntut seorang penulis harus bersifat "perspektif emic" artinya memperoleh data bukan "sebagaimana seharusnya" tetapi berdasarkan sebagaimana adanya yang dialami dan difikirkan oleh partisan/sumber data. Penelitian ini bersifat deskriptif analitik yaitu mengumpulkan atau memaparkan Pemikiran KH. MA. Sahal Mahfudh tentang pendidikan ekologis serta menganalisanya dengan menggunakan pendekatan atau teori yang telah ada.

Dalam penelitian ini penulis menggunakan pendekatan historis-filosofis yaitu penelitian yang berupaya menganalisis secara kritis terhadap pemikiran, peristiwa, perkembangan dan pengalaman masa lalu, kemudian menggali sejauh mungkin landasan pemikirannya. Sehingga dapat menganalisa secara kritis terhadap pemikiran KH. MA. Sahal Mahfudh. Pendekatan lain yang digunakan dalam penelitian ini adalah pendekatan tematis. Arief Furchan dan Agus Maimun, menyatakan bahwa pendekatan ini untuk mendeskripsikan aktivitas seseorang berdasarkan sejumlah tema (topik) yang dipakai untuk mempelajari suatu bidang keilmuan tertentu. Dalam penelitian ini secara khusus untuk mengetahui pemikiran KH. MA. Sahal Mahfudh.

metode pengumpulan data yang digunakan yakni dokumentasi dimana pada teknik ini peneliti dimungkinkan memperoleh informasi dari bermacam-macam sumber tertulis atau dokumen yang ada pada responden atau tempat, di mana responden bertempat tinggal atau melakukan kegiatan sehari-harinya. Karena itu panduan utamanya adalah karya-karya KH. MA. Sahal Mahfudh yang membahas tentang lingkungan hidup. Selain dokumentasi juga menggunakan wawancara tidak terstruktur, menurut Arikunto (Suharsimi, 2002, P: 202) wawancara tidak terstruktur yaitu wawancara yang hanya memuat garis besar permasalahan yang akan ditanyakan. Pihak yang akan diwawancarai ialah keluarga dan atau murid-murid Kiai Sahal yang banyak belajar dan berinteraksi dengan Kiai Sahal. Wawancara ini diharapkan dapat memperoleh data secara lebih mendalam dan komprehensif yang tidak terdapat dalam buku atau karya Kiai Sahal lainnya.

Maksud pokok mengadakan analisa adalah melakukan pemeriksaan konsepsional atas makna yang dikandung oleh istilah-istilah yang digunakan dan pernyataan-pernyataan yang 
dibuat. Di sini dibutuhkan kejelian dan ketelitian dalam membaca data. Dalam menganalisis data, penulis berusaha menggunakan beberapa metode analisis isi (content analysis), sebuah analisis yang berangkat dari aksioma bahwa studi tentang proses isi komunikasi itu merupakan dasar bagi ilmu sosial. Content Analysis merupakan analisis ilmiah tentang isi pesan suatu komunikasi (Noeng Muhadjir, 2002, P: 68). Selain metode tersebut juga digunakan Metode interpretatif, yaitu metode yang menggunakan karya tokoh kemudian diselami untuk menangkap arti dari nuansa yang dimaksudkan tokoh secara khas. Maksudnya adalah menganalisa karya atau hasil pemikiran tokoh yang diangkat dalam penelitian untuk diungkap arti serta nuansa yang disajikan, bukan hanya memahaminya berdasarkan teks belaka.

\section{Pembahasan}

\section{Konsep Pendidikan Eko-Religius KH. MA. Sahal Mahfudh}

KH. MA. Sahal Mahfudh merupakan produk asli pesantren tradisional namun memiliki pemikiran yang sangat luas dalam berbagai bidang kehidupan. Pemikiran KiaiSahal bersifat kontekstual sesuai perkembangan zaman dengan tidak meninggalkan landasan hukum dasar dari al-Quran dan al-hadits, serta Ijma' dan Qiyas. Salah satu pemikiran revolusioner dari KiaiSahal ialah Fiqh Sosial, di mana fiqh dipahami secara manhaji, bukan sekedar qauli. Fiqh bukan hanya berbicara halal-haram atau hitam-putih, lebih dari itu fiqh dijadikan pedoman untuk memberdayakan masyarakat dengan melihat konteks sosial budaya serta kemaslahatan umat sebagai pertimbangan. Apabila ditelusuri lebih dalam, pemikiran KiaiSahal sangat beragam dan menyentuh berbagai aspek kehidupan. Salah satu bidang kajian fiqh sosial yang ditulis KiaiSahal namun tidak banyak disinggung oleh santri maupun kebanyakan masyarakat ialah tentang lingkungan hidup (ekologis). Tema tentang ekonomi, sosial, atau pendidikan Islam lebih menarik perhatian banyak penulis yang ingin mengangkat pemikiran KiaiSahal. Sehingga pemikiran beliau tentang lingkungan hidup tidak banyak diketahui masyarakat.

Hal ini dapat dipahami karena sangat sedikit tulisan beliau yang secara eksplisit membahas tentang lingkungan hidup. Namun, jika ditelusuri lebih jauh akan ditemukan banyak pemikiran beliau yang menyinggung tentang lingkungan hidup sebagai bagian yang tak terpisahkan dari kehidupan manusia. Pemikiran tentang lingkungan hidup tersebut secara implisit terdapat dalam berbagai tulisan beliau sehingga membutuhkan analisis yang mendalam. Pemikiran KiaiSahal tentang lingkungan hidup perlu diangkat ke permukaan supaya dikenal oleh masyarakat. Maka dari itu, judul dari penelitian ini ialah menguak 
konsep pendidikan eko-religius KH. MA. Sahal Mahfudh. Pemikiran beliau harus dikuak, digali, kemudian dikeluarkan dari tumpukan pemikiran dalam bidang-bidang lain. Hasil dari penggalian itu akhirnya ditemukan sebuah konsep pemikiran berkaitan dengan lingkungan hidup, yakni manusia mempunyai tugas mengelola alam ini dengan baik sesuai ajaran agama Islam. Untuk mencapai hal tersebut, pendidikan menjadi salah satu kunci dalam mewujudkannya.

Itulah alasan penulis memberikan istilah pendidikan eko-religius dalam pemikiran KiaiSahal tentang lingkungan hidup. Eko-religius berasal dari dua kata, yakni ekologi dan religius. Ekologi berarti berbicara tentang hubungan timbal balik antara manusia dengan lingkungan di sekitarnya (baik benda hidup maupun benda tak hidup). Sementara religius dapat diartikan sebagai sesuatu yang bersifat keagamaan dan kepercayaan kepada yang Maha Kuasa. Religius di sini berarti berasal dari ajaran-ajaran agama Islam. Maka pendidikan ekoreligius secara sederhana dapat disimpulkan sebagai sebuah proses pendidikan tentang lingkungan hidup dengan ajaran Islam sebagai landasannya. Menjadikan religiusitas sebagai titik tolak pendidikan ekologis bukanlah tanpa alasan. Ajaran Islam atau lebih khususnya syariat Islam mempunyai titik singgung yang sangat kompleks dengan masalah-masalah sosial. Karena syariat Islam itu sendiri justru mengatur hubungan antara manusia (individual maupun kelompok) dengan Allah SWT, antara sesama manusia, dan antara manusia dengan alam lingkungannya. (Sahal Mahfudh, 2011, P 212) Menurut KiaiSahal, manusia merupakan hamba Allah yang tugasnya ialah ibadatullah (beribadah kepada Allah). Akan tetapi, selain sebagai hamba Allah manusia juga dijadikan sebagai khalifah atau wakil Allah di bumi dengan tugas dan wewenang yang harus dijalankan. Tugas itu dalam al-Quran disebut 'imaratul ardhi yang berarti mengelola dan memelihara bumi, tentu saja bukan sekedar membangun tanpa tujuan apalagi hanya untuk kepentingan diri sendiri.(Sahal Mahfudh; 2011, P: 64) Pembangunan yang tidak dibarengi dengan pemeliharaan dan pengelolaan terhadap alam tentu akan berakibat pada rusaknya alam dan lingkungan tempat manusia hidup. Demi menjaga kelestarian lingkungan di tengah keinginan manusia untuk menguasainya sesuka hatinya, maka perlu diberikan pendidikan tentang alam dan lingkungan. KiaiSahal mengingatkan:

Pembinaan lingkungan hidup dan pelestariannya menjadi amat penting artinya untuk kepentingan kesejahteraan hidup di dunia maupun di akhirat, di mana aspekaspeknya tidak dapat terlepas dari air, hewan, tumbuh-tumbuhan, dan benda-benda lain sebagai unsur pendukung. Keseimbangan dan keserasian antar semua unsur 
tersebut sangat mempengaruhi dan dipengaruhi oleh sikap rasional manusia yang berorientasi pada kemaslahatan makhluk. (Sahal Mahfudh, 2011, P: 390)

Kiai Sahal juga menjelaskan bahwa ajaran agama Islam terutama yang berhaluan ahlussunnah wal jamaah (aswaja) -seperti NU- harus mampu menjadi panutan dalam mengelola alam dengan baik. Aktualisasi nilai-nilai aswaja dalam pelestarian lingkungan hidup -menurut KiaiSahal- harus bisa mendorong pengikutnya dan umat pada umumnya agar mampu bergaul dengan sesamanya dan alam sekitarnya untuk saling memanusiawikan. ${ }^{1}$ Aktualisasi Islam Aswaja yang disampaikan Kiai Sahal bukan sekedar konsep idealis belaka, tetapi berasal dari realitas sosial yang dialami umat, salah satunya tentu saja masalah ekologis. Untuk itulah perhatian terhadap lingkungan hidup menjadi salah satu sasaran aktualisasi nilai aswaja. Di sini sangat jelas bagaimana konsep pendidikan eko-religius Kiai Sahal. Berangkat dari kenyataan bahwa masalah ekologis semakin besar dan membahayakan serta mengancam kehidupan manusia. Kiai Sahal memberi tawaran pendidikan lingkungan hidup dengan ajaran Islam sebagai landasan pijaknya. Tidak hanya itu, pesantren sebagai salah satu lembaga pendidikan Islam diberikan mandat besar untuk menjadi contoh dalam pelestarian alam dan lingkungan. Hal inilah yang menjadi kekhasan pemikiran beliau dalam bidang lingkungan hidup.

Permasalahan ekologi menurut Kiai Sahal masuk dalam masalah-masalah sosial keagamaan Islam yang meliputi semua aspek kehidupan sosial. Sementara itu, ajaran Islam telah meletakkan landasan yang kuat dan fleksibel bagi sikap dan perilaku dalam disiplin sosial. Disiplin sosial ini juga berlaku dalam pengelolaan alam sesuai ajaran Islam. Konsep pendidikan ekologis dengan menjadikan ajaran Islam sebagai landasannya merupakan gagasan dari Kiai Sahal yang dituangkan dalam karya-karya beliau. Bahkan konsep pendidikan eko-religius secara matang dapat diambil dalam pemikiran fiqh sosial ala KiaiSahal. Konsep pendidikan eko-religius KiaiSahal berbicara tentang tujuan, strategi dan metode, bahkan sampai pada tahap evaluasi dari pendidikan eko-religius.

\section{Tujuan Pendidikan Eko-Religius}

Berbicara tentang pendidikan pasti tidak akan bisa lepas dari tujuan pendidikan itu sendiri. Tanpa adanya tujuan maka pendidikan akan disoriented, tidak tentu arah dan tanpa target jelas yang ingin dicapai. Demikian pentingnya posisi tujuan dalam pendidikan karena akan menentukan apa dan bagaimana proses pendidikan dijalankan. Demikian pula dalam konsep pendidikan eko-religius dalam pemikiran KiaiSahal, semua berawal dari tujuan atau 
cita-cita yang mulia. Pendidikan adalah proses pembentukan watak manusia secara utuh, baik dari sisi esensialnya sebagai makhluk yang terdiri dari jasad lahiri, akal, nafsu, dan perasaan maupun dari sisi kehidupannya sebagai makhluk sosial. Pendidikan Islam adalah proses pembentukan watak, sikap, dan perilaku islami meliputi iman (akidah), Islam (syariat), dan ihsan (akhlak, etika, dan tasawuf). Tujuan pokoknya -termasuk pendidikan di pesantrenpada dasarnya mempersiapkan para santri agar menjadi manusia yang "akrom" dan "shalih" dengan pengertian yang luas. Pengertian yang luas berarti dapat diterapkan dalam pendidikan apa saja dan di mana saja, dalam konteks ini yaitu pendidikan lingkungan hidup yang berlandaskan ajaran agama Islam.

Tujuan pendidikan eko-religius -menurut Kiai Sahal sebagaimana pengertian pendidikan di atas- dapat ditarik dari tujuan akhir dari manusia yaitu sa'adatuddarain (mencapai kebahagiaan di dunia dan di akhirat), kemudian diturunkan menjadi tujuan umum pendidikan di pesantren, yakni membentuk dan mempersiapkan manusia yang akram dan shalih. Konsep shalih dan akram inilah yang selalu dikembangkan Kiai Sahal dalam beraktivitas dan berkarya di berbagai bidang kehidupan, baik politik, sosial, budaya, ekonomi, dan lain-lain. Pendidikan eko-religius Kiai Sahal menjelaskan bahwa manusia yang akram adalah manusia yang paling bertaqwa kepada Allah SWT. Taqwa ini kemudian dimanivestasikan dalam diri manusia shalih yaitu mereka yang mampu mewarisi bumi ini dalam arti luas mengelola, menyeimbangkan, dan melestarikan alam. Dalam al-Quran surat al-Anbiya' 105 disebutkan bahwa:

Sesungguhnya bumi ini diwariskan kepada orang-orang yang shalih

Agar terbentuk karakter manusia dengan kemampuan mengelola dan melestarikan alam, dibutuhkan proses pendidikan. Pendidikan eko-religius berarti membekali diri dengan pengetahuan, sikap, dan perilaku dalam mengelola alam dengan bijak. Sebagai khalifah, manusia memiliki tanggung jawab terhadap diri sendiri -selain terhadap orang lain- yang berarti keharusan meningkatkan kemampuan pribadi untuk memusatkan dirinya pada pewarisan bumi (alam) dalam rangka ibadah yang sempurna. Perlu diingat bahwa tanggung jawab utama seorang muslim tentu saja kepada Allah SWT dalam bentuk disiplin norma dan ajaran di dalam pengelolaan alam. Disiplin ini dilakukan dalam rangka meningkatkan "keakram-an" yang dapat menumbuhkan lingkungan hidup yang seimbang dan serasi. Manusia yang akram dan shalih dalam mengelola dan melestarikan bumi (alam) menjadi tujuan pendidikan eko-religius. Alam lingkungan yang lestari berarti membuka jalan kesuksesan hidup manusia. Dalam konteks fiqh, kesuksesan yakni tercapainya kemaslahatan dalam 
maqhasid asy-syari'ah yakni terjaminnya seseorang dalam mengembangkan agama, jiwa, keturunan, akal, dan harta benda. Kelima unsur pokok kemaslahatan tersebut hanya dapat berjalan dengan baik apabila alam dan lingkungan sebagai tempat hidup manusia terjaga dan dikelola dengan baik pula. Manusia yang akram dan shalih akan mengelola alam sesuai tuntunan ajaran agama Islam untuk mencapai kebahagiaan di dunia dan di akhirat.

\section{Pendekatan dan Strategi Pendidikan Eko-Religius}

Pendidikan merupakan proses sadar dan terencana menyiapkan generasi masa depan agar menjadi lebih dewasa dan berakhlak mulia. Terdapat tiga ranah sasaran perubahan dari proses pendidikan, yaitu ranah kognitif, afektif, dan psikomotorik. Ranah kognitif yakni wilayah pengetahuan akademik yang harus dikuasai, sementara ranah afektif ialah sikap yang harus dimiliki seseorang setelah menempuh pendidikan. Ranah ketiga yaitu psikomotorik yang merupakan tingkah laku dan akhlak dalam menghadapi segala sesuatu. Pendidikan bertujuan membentuk akhlak dan perilaku yang baik dalam kehidupan seharihari. Begitu pula pendidikan eko-religius, agar berhasil membentuk karakter manusia yang akram dan shalih dalam mengelola alam maka ketiga ranah pendidikan harus diperhatikan. Menurut KiaiSahal, langkah awal yang perlu ditempuh dalam pendidikan eko-religius ini ialah pengenalan masalah-masalah lingkungan hidup dan implikasinya terhadap segala aspek kehidupan. Di sini proses transfer of knowledge yang menekankan pada pengetahuan kognitif menjadi poin utama. Tanpa pengetahuan dan pemahaman kognitif, mustahil akan terbentuk karakter dan watak peduli lingkungan. Bagaimanapun juga, pengetahuan akan lingkungan hidup sangat penting sebagai modal awal untuk mengembangkan sikap dan perilaku peduli lingkungan.

Kemudian langkah selanjutnya ialah penumbuhan kesamaan wawasan keagamaan yang mampu memotivasi dalam mencari sendiri alternatif pemecahannya sesuai potensi yang dimiliki ( Sahal Mahfudh, 2011, P: 394) Di sini aspek afektif dan psikomotorik lebih diutamakan, yakni menjadikan pengetahuan yang dimiliki semakin berkembang, bisa memotivasi diri sendiri untuk terus maju, serta mampu memberikan solusi alternatif dari permasalahan lingkungan yang dihadapi masyarakat. Perbedaan problematika serta kultur dan norma yang berlaku di masyarakat, memerlukan solusi dan jalan keluar yang berbeda-beda. Maka tidak ada solusi tunggal dalam menghadapi problem lingkungan. Solusi pemecahannya harus disesuaikan dengan budaya masyarakat setempat agar tidak muncul problem baru di kemudian hari. Pendidikan eko-religius diharapkan mampu menjadi bekal penting bagi santri 
maupun kaum muslimin pada umumnya untuk berinovasi menyelesaikan masalah lingkungan hidup berbasis kearifan lokal.Untuk mencapai hal tersebut, diperlukan pendekatan dan strategi yang tepat dalam menanamkan dan memunculkan karakter peduli lingkungan. Pendekatan dalam pendidikan eko-religius dapat dilakukan dengan tiga macam pendekatan (Sahal Mahfudh, 2011, P: 392), yaitu pendekatan proyek, pendekatan motivasi, dan pendekatan kolaboratif antara proyek dan motivasi.

\section{Pendekatan proyek}

Pendekatan proyek berarti sebuah metode pembelajaran dalam pendidikan yang menggunakan proyek/kegiatan sebagai media. Peserta didik melakukan eksplorasi, penilaian, interpretasi, sintesis, dan informasi untuk menghasilkan berbagai bentuk hasil belajar. Pembelajaran dengan pendekatan proyek merupakan metode belajar yang menggunakan masalah sebagai langkah awal dalam mengumpulkan dan mengintegrasikan pengetahuan baru berdasarkan pengalamannya dalam beraktifitas secara nyata. Proses pembelajaran pendidikan eko-religius dengan pendekatan proyek dapat dilakukan dengan menentukan proyek, masalah, atau kegiatan terlebih dahulu di awal. Proyek tersebut dapat berupa kegiatan kerjasama dengan pihak lain yang bergerak di bidang lingkungan atau kegiatan yang sengaja dirancang untuk pembelajaran dengan tujuan menanamkan dan menumbuhkan kepedulian terhadap lingkungan, serta melahirkan generasi yang shalih dalam mengelola alam. Semakin banyak proyek atau kegiatan maka semakin besar pula kemungkinan tumbuhnya karakter peduli lingkungan. Akan tetapi, pendekatan proyek hasil kerjasama dengan pihak lain jumlahnya tentu tidak banyak. Selain itu pula dibutuhkan dana besar untuk mengerjakan proyek pembinaan lingkungan hidup sehingga tidak setiap lembaga dapat melakukannya.

Proyek seperti pembuatan gorong-gorong, sanitasi, penyaring limbah, atau penanaman pohon memang berorientasi pada sikap peduli lingkungan. Namun hal itu kurang mengena dalam menanamkan dan menumbuhkan sikap peduli lingkungan terhadap peserta didik. Proyek atau kegiatan yang disiapkan dalam proses pembelajaran akan lebih mengena dan tepat sasaran, yakni memberikan pelajaran tentang lingkungan hidup dan implikasinya dalam kehidupan. Yang patut diperhatikan apabila menggunakan pendekatan proyek terutama proyek besar hasil kerjasama dengan pihak lain ialah kesesuaian proyek dengan masalah yang dihadapi masyarakat serta kultur dan norma setempat. Maka diperlukan pola pendekatan yang berorientasi pada kenyataan di masing-masing daerah yang berbeda, dalam hal wawasan, potensi, antisipasi ke depan, maupun tenaga ahli dan tenaga dukungnya (Sahal Mahfudh, 
2011, P: 394) Apabila proyek yang ada bukanlah solusi yang dibutuhkan masyarakat tentu saja hal itu akan sia-sia belaka.

\section{Pendekatan motivasi}

Pendekatan motivasi di sini berarti pendidikan eko-religius yang dilakukan melalui proses pemberian motivasi kepada sasaran (peserta didik) agar tertanam pengetahuan dan tumbuh sikap peduli lingkungan hidup. Dapat dikatakan bahwa pendekatan motivasi merupakan sebuah pembelajaran dengan penekanan pada proses yang baik, bertahap, dan terus-menerus. Proses pembelajaran yang bertahap -dari materi yang sederhana menuju kompleks- dan dilakukan secara kontinu akan mampu memberikan motivasi peserta didik untuk terus belajar dan memahami tentang pendidikan lingkungan hidup.

Proses pendidikan eko-religius yang dilakukan dengan baik besar kemungkinan membuahkan hasil yang baik pula. Perilaku dan sikap acuh tak acuh pada lingkungan hidup akan berubah menjadi suatu sikap dinamis yang akan terus berkembang dan akan berkulminasi pada stabilitas pembinaan lingkungan hidup.(Sahal Mahfudh, 2011, P: 393) Dari sini Kiai Sahal lebih menekankan pembentukan karakter melalui proses pembelajaran daripada pendekatan proyek. Penerapan pendidikan eko-religius dapat dilakukan dengan cara integatif ke dalam komponen akidah, syariah, dan akhlak. Bagi lembaga pendidikan dilakukan dengan penyisipan materi lingkungan hidup ke dalam mata pelajaran yang telah ada dan relevan dengan materi dan aspek kependudukan. Kelebihan cara ini antara lain (1) tidak menaKiaibeban guru dan peserta didik, (2) tidak perlu menaKiaikomponen pelajaran baru, (3) pengaruhnya bagi peserta didik dalam penghayatan dan penyadaran merubah sikap cukup positif, karena pendidikan kependudukan itu secara inklusif dihayati bersama menghayati pelajaran yang disisipi, apalagi bagi pelajaran agama, (4) pola keterpaduan dengan pelajaran lain tidak ada jarak, bahkan menyatu, di mana hal ini sangat besar manfaatnya bagi peserta didik dalam memperluas wawasan hidupnya, (5) tidak perlu merumuskan metode baru, akan tetapi bisa langsung menggunakan metode pelajaran itu sendiri.

Integrasi pendidikan lingkungan hidup dalam pembelajaran sudah digagas oleh Kiai Sahal sejak lama. Hal ini menunjukkan pemikiran beliau sangat visioner dan berangkat dari analisis yang tajam berdasarkan realitas yang ada di masyarakat. Dalam lingkup formal, agar pendidikan eko-religius tidak menitikberatkan mata pelajaran maka materinya dapat diintegrasikan dalam beberapa mata pelajaran termasuk pendidikan Islam. Menurut beliau, pendidikan -lingkungan hidup- dilakukan secara integratif ke dalam komponen-komponen 
akidah, syariah, dan akhlak. Jadi semua elemen dalam ajaran Islam dijadikan sarana untuk menanamkan dan menyebarkan pendidikan lingkungan hidup. Pendekatan motivasi walaupun akan memerlukan waktu yang relatif panjang, akan berdampak lebih positif karena pihak sasaran secara berangsur akan mau mengubah sikap dan perilaku secara persuasif. (Sahal Mahfudh, 2011, P: 392) Apabila karakter manusia akram dan shalih dalam mengelola alam dan lingkungan telah terbentuk, maka sikap dan perilaku akan selalu menunjukkan kepedulian terhadap kelestarian lingkungan sehingga akan meningkatkan sarana keberhasilan mencapai sa'adatuddarain.

\section{Pendekatan kolaboratif}

Pendekatan ketiga dalam pendidikan eko-religius KiaiSahal yakni pendekatan kolaboratif antara pendekatan proyek dengan pendekatan motivasi. Pelaksanaan dari pendidikan ini dapat diawali dengan pendekatan motivasi dilanjutkan menggarap sebuah proyek atau kegiatan dengan tema lingkungan hidup. Atau dimulai dengan proyek terlebih dahulu untuk kemudian dikuatkan dalam bentuk pendekatan motivasi. Bentuknya dapat disesuaikan dengan kebutuhan, kondisi lingkungan sosial budaya, dan kemampuan lembaga pendidikan dalam menyelenggarakannya. Pendekatan ketiga ini dinilai lebih tepat dan mengena bagi pembinaan lingkungan hidup. Proses pendidikan dengan pendekatan motivasi mencoba untuk menanamkan dan menumbuhkan kesadaran akan pentingnya lingkungan hidup bagi kehidupan sesuai ajaran agama Islam. Pengetahuan dan pemahaman tersebut akan sangat tepat apabila dilengkapi dengan praktik langsung berupa pendekatan proyek sehingga konsep dan teori yang didapat dapaat diimplementasikan secara langsung dalam bentuk proyek atau kegiatan.

Sebagai ulama yang lahir dan berkembang di lingkungan pesantren, KiaiSahal menawarkan pesantren untuk turut andil dalam upaya pembinaan lingkungan hidup. Ketiga pendekatan dalam pendidikan eko-religius di atas bisa diadaptasi dan diterapkan dalam pendidikan pesantren. Optimisme tinggi akan keberhasilan pesantren memegang amanah ini telah diutarakan beliau dalam tulisannya. Pesantren merupakan lembaga pendidikan yang berbasis pada masyarakat sehingga peran pesantren sangat dinantikan untuk membantu menyelesaikan berbagai permasalahan yang timbul dalam kehidupan masyarakat, termasuk permasalahan lingkungan hidup. Kemungkinan proyeksi pesantren pada pembinaan lingkungan hidup itu perlu perumusan matang -agar memiliki tingkat keberhasilan yang tinggi-. KiaiSahal memberikan beberapa pilihan, apakah pesantren bertindak sebagai penunjang atau pelengkap, ataukah sebagai motivator, dinamisator, dan fasilitator? (Sahal 
Mahfudh; 2011, P: 395) Semuanya harus disesuaikan dengan kondisi sosial budaya serta kemampuan dan kemauan masing-masing pesantren. Maka tidak ada konsep tunggal yang harus dijalankan oleh semua pesantren, semuanya harus sesuai kebutuhan dan kearifan lokal agar imbasnya lebih dirasakan masyarakat.

\section{Evaluasi Pendidikan Eko-Religius}

Proses pendidikan pesantren telah terbukti berhasil menghasilkan alumni dengan karakter yang kuat. Prestasi yang dapat dilihat adalah munculnya para alumni yang mendapat legitimasi dari masyarakat sebagai ulama atau kiai. Mereka dinilai tangguh dan mampu mengembangkan dirinya di bidang keilmuan agama Islam, juga memiliki kepekaan tinggi terhadap masalah sosial dan lingkungan. Jadi keberhasilan suatu proses pendidikan indikatornya ialah penilaian masyarakat dari apa yang telah dilakukan seseorang di kehidupan sosialnya. Demikian pula penilaian terhadap keberhasilan proses pendidikan ekoreligius, sangat bergantung dari seberapa besar peran yang dilakukan dalam kehidupan nyata. Evaluasi pendidikan eko-religius bukan lagi menggunakan tes akademik, melainkan memakai standar penilaian kinerja. Semakin banyak yang dilakukan dalam upaya melestarikan lingkungan hidup, semakin menunjukkan keberhasilan pendidikan eko-religius. Selain itu, keaktifan dalam melestarikan lingkungan harus dilandasi dengan kehidupan religius yang semakin matang. Kematangan beragama Islam salah satunya ditunjukkan dengan mengaktualisasikan ajaran Islam dalam kehidupan nyata mengelola alam dengan baik. Mereka yang miskin nilai-nilai agama -menurut KiaiSahal- berpotensi besar memanfaatkan alam hanya untuk kepentingan dan keuntungan pribadi semata. Sesuai dengan tujuan pendidikan eko-religius, yakni melahirkan insan yang akram dan shalih, maka evaluasinya tentu saja bertolak dari tercapainya tujuan. Shalih merupakan manivestasi dari akram, mereka yang paling bertaqwa pasti akan menunjukkan dalam perilaku sehari-hari sebagai manusia yang shalih. Dalam hal ini yaitu manusia yang bukan hanya rajin beribadah formal (perintah utama), tetapi juga yang mampu menjalankan amanah sebagai khalifah dengan mengelola alam dan bumi sebaik mungkin dan menjaga kelestariannya.

\section{Diseminasi Pendidikan Eko-Religius KH. MA. Sahal Mahfudh}

Pendidikan eko-religius yang diajarkan KiaiSahal dalam beberapa tulisan makalah serta buku, bukan sekedar teori saja. Konsep pendidikan eko-religius tersebut juga diajarkan melalui uswah hasanah (suri teladan yang baik) oleh Kiai Sahal. Bahkan menurut Gus Rozien, sangat jarang sekali Kiai Sahal mengajarkan tentang lingkungan hidup serta akhlak lain dengan instruksi atau perintah. Beliau lebih banyak mengajari keluarga dan santri- 
santrinya melalui contoh perilaku yang beliau lakukan sendiri. Hal ini terlihat ketika KiaiSahal mengajak masyarakat untuk peduli lingkungan terutama dalam hal liKiaiair rumah tangga. LiKiaiair rumah tangga yang dihasilkan dari rumah KiaiSahal dan Pesantren Maslakul Huda setiap harinya selalu ada, baik untuk mandi, mencuci, ataupun wudlu para santri. Karena aliran liKiaiair dari pondok menuju ke sungai lumayan jauh, maka KiaiSahal membuat gorong-gorong agar bau dari liKiaitersebut tidak mengganggu masyarakat. Padahal waktu itu yang lazim di masyarakat adalah -bahasa Jawanya- peceren, yaitu aliran Kiai yang terbuka, sementar gorong-gorong aliran yang tertutup. Beliau yang menginisiasi pertama kali kemudian mengajak beberapa rumah yang dilewati aliran Kiai dari pondok menuju sungai. Dengan demikian, liKiaiair yang berbau kalau menggunakan peceren dapat diatasi sehingga tidak mengganggu masyarakat. KiaiSahal member contoh terlebih dahulu kemudian mengajak kepada yang lain. Apa yang disampaikan dan diajarkan KiaiSahal merupakan bagian dari diseminasi pendidikan eko-religius. Banyak teladan beliau yang bisa menjadi pelajaran untuk melestarikan lingkungan sebagai tempat manusia hidup dan berkembang. Diseminasi pendidikan eko-religius yang dilakukan KiaiSahal bahkan terdapat dalam berbagai bidang kehidupan sejalan dengan gagasan fiqh sosial beliau. Bidang-bidang tersebut antara lain pendidikan, ekonomi dan pemberdayaan masyarakat, serta sosial.

\section{Pendidikan}

Bidang pendidikan menjadi lahan diseminasi konsep pendidikan eko-religius yang sangat tepat untuk menanamkan dan menumbuhkan karakter peduli lingkungan hidup sesuai ajaran agama Islam. Karena Kiai Sahal lahir dan berkembang dari dunia pesantren, maka diseminasi di bidang pendidikan ini akan banyak membahas peran pesantren dalam pembinaan lingkungan hidup sebagaimana digagas Kiai Sahal. Sebagai lembaga pendidikan Islam yang hidup berdampingan dengan masyarakat, pesantren diharapkan mampu memberikan solusi dari setiap permaslahan yang dihadapi masyarakat. Pesantren tidak boleh jauh dari realitas yang dialami dan berkembang di kehidupan sosial agar ilmu yang dipelajari di pesantren dapat diterapkan dengan baik. Dalam buku Nuansa Fiqh Sosial yang merupakan kumpulan tulisan Kiai Sahal terdapat salah satu tulisan yang dengan jelas menunjukkan peran pesantren dalam upaya melestarikan lingkungan dan alam sekitar. Tulisan tersebut diberi judul Pesantren dan Pembinaan Lingkungan Hidup, sangat eksplisit menunjuk pesantren sebagai tempat membina (mengajar dan mendidik) para santri agar peduli terhadap lingkungan. 
Tulisan tersebut ditulis Kiai Sahal pada tahun 1988, era di mana kerusakan lingkungan belum separah tahun 2000an. Akan tetapi Kiai Sahal dengan pemikiran visionernya sudah mampu memprediksi parahnya kerusakan alam dan lingkungan oleh ulah manusia sendiri. Beliau menyebutnya dengan mulai tergesernya keseimbangan dan kelestarian lingkungan hidup. Maka dari itu Kiai Sahal melalui pesantren berharap dapat melakukan pembinaan lingkungan hidup agar tidak menyulitkan generasi masa depan. Kiai Sahal optimis pesantren mampu dan mau melaksanakan amanah tersebut. Diseminasi pendidikan eko-religius melalui bidang pendidikan -dalam hal ini utananya adalah pesantrenmerupakan langkah yang tepat. Menurut Kiai Sahal, pesantren mempunyai peran ganda, pertama sebagai lembaga pendidikan yang mampu mengembangkan pengetahuan dan penalaran, serta keterampilan dan kepribadian kelompok muda. Kedua selain sebagai lembaga pendidikan, pesantren sekaligus berperan sebagai lembaga sosial yang memiliki peran sosial dan bisa menggerakkan swadaya dan swakarsa masyarakat. Peran ganda tersebut memungkinkan pesantren akan mampu melakukan perbaikan lingkungan hidup.

Melalui jalur pendidikan inilah penanaman dan penumbuhan sikap cinta lingkungan dan peduli terhadap kelestariannya dapat dipupuk dengan baik. Pendidikan eko-religius sebagai bukti bahwa pembinaan lingkungan hidup yang digagas Kiai Sahal merupakan pemikiran mendalam hasil analisis terhadap realitas sosial dengan landasan ajaran agama Islam. Kemampuan analisis beliau sudah tidak diragukan lagi, oleh Kiai Sahal, ajaran agama Islam terutama hukum Islam (fiqh) bukan dijadikan hukum yang kaku tetapi diinterpretasikan sesuai kondisi sosial yang dihadapi zamannya. Aktualisasi dan kontekstualisasi fiqh inilah yang menjadi kekhasan pemikiran dan aksi Kiai Sahal. Pendidikan menjadi jalur tepat untuk menyemai pemikiran beliau dan meneruskannya kepada generasi mendatang.

\section{Ekonomi}

Mulai tahun 80an Kiai Sahal mendirikan BPPM, yang banyak disorot dari BPPM adalah masalah ekonomi kemasyarakatan dan pemberdayaan masyarakat. Tetapi sebetulnya dalam beberapa kegiatan ada yang berkaitan dengan lingkungan hidup. Berbeda dengan masalah ekonomi yang menyentuh langsung pada kebutuhan hidup masyarakat, sehingga ekonomi terlihat dan terukur hasilnya. Persoalan lingkungan hidup yang kemudian oleh sebagian besar masyarakat -baik pesantren maupun luar pesantren- pada era 80an belum dianggap sebagai kebutuhan dan masalah dasar. Maka kemudian keberhasilannya tidak begitu diperhatikan masyarakat. Yang menarik dari pemberdayaan ekonomi masyarakat yang digagas oleh Kiai Sahal dan BPPM-nya ialah bahwa kemajuan ekonomi tidak boleh 
melupakan kelestarian lingkungan. Manusia memang diperintahkan untuk mengelola alam, perintah mengelola berarti bukan hanya mengeksploitasi manfaatnya tetapi juga merawat dan menjaga kelestariannya sehingga generasi berikutnnya masih bisa menikmati. Integrasi pendidikan eko-religius dalam bidang ekonomi menjadi gagasan visioner yang belum pernah dipikirkan sebelumnya oleh kebanyakan orang.

Diseminasi pendidikan eko-religius dalam bidang ekonomi diantaranya BPPM pernah menginisiasi dan merancang teknologi tepat guna untuk mengatasi polusi air di sungai Ngemplak akibat liKiaiindustri tepung tapioka. BPPM menawarkan sistem produksi yang dapat membuat air pembuangannya jatuh ke sungai dalam kondisi yang tidak begitu mencemari sungai. BPPM bekerjasama dengan Undip dan LP3S melakukan penelitian sekaligus menawarkan sistem produksi yang ramah lingkungan tetapi tidak membebani biaya produksi sehingga tidak memberatkan pengusaha. Air hasil teknologi ini memang belum sepenuhnya bersih tetapi setidaknya dari bau dan warnanya sudah tidak begitu mencemari sungai dan habitat yang ada di dalamnya. Proyek ini tentu saja membutuhkan kesadaran dari pengusaha, mengajak pengusaha untuk sadar lingkungan itu sesuatu yang luar biasa susahnya. Saat itu hanya ada 3 atau 4 pabrik dari belasan pabrik yang bersedia bekerjasama dan menggunakan teknologi tersebut. Karena mayoritas pabrik tidak bersedia, maka ketika alatnya rusak tidak lagi diperbaiki oleh pabrik yang menggunakan alat tadi.

Bukan itu saja, dalam rapat pembahasan masalah air liKiaiindustri tepung ini, Kiai Sahal sudah mengingatkan akan dampak negatif dari air liKiaiterhadap ekosistem dan lingkungan. Dampak tersebut seperti sawah yang seharusnya mendapatkan air bersih untuk irigasi menjadi tidak mendapatkan air bersih, atau sungai yang seharusnya ada ikannya menjadi sangat sedikit ikan di sungai karena airnya tercemar. Orang yang ingin memanfaatkan air dari sungai menjadi tidak bisa memanfaatkan hanya karena kegiatan ekonomi yang menguntungkan beberapa pihak saja.

\section{Sosial}

Dalam bidang sosial kemasyarakatan, peran Kiai Sahal sangat besar baik berupa gagasan atau aktivitas yang beliau lakukan. Dari kepedulian sosial ini pula yang pada akhirnyaa melahirkan gagasan fenomenal "Fiqh Sosial", fiqh yang dekat dengan realitas sosial, bukan yang kaku dan hanya berbicara hitam atau putih, halal atau haram. Peran beliau dalam hal gizi bagi anak dan balita, perencaan keluarga melalui KB, serta gagasan lainnya sungguh sangat luar biasa. Dakwah beliau bukan sekedar ceramah tetapi langsung menuju ke sasaran dengan aksi nyata mengatasi persoalan.Bidang sosial masyarakat ini pula yang 
dijadikan Kiai Sahal untuk menyebarkan dan mengembangkan pendidikan eko-religius. Bukan dengan pendekatan motivasi semata, tetapi melalui pendekatan proyek sehingga masyarakat merasakan betul dampaknya. Dalam bidang sosial, memang pendekatan proyek dirasa lebih tepat tetapi tentu saja dengan tetap memberikan pelajaran dan motivasi agar masyarakat peduli lingkungan dan tidak memanfaatkannya secara semena-mena.

Contoh nyata dari dakwah tersebut ialah Kiai Sahal melalui BPPM pernah melakukan pemberdayaan masyarakat untuk mendapat air bersih di desa Pancur, Sreni, Jepara, sekitar tahun 1984-1986. Pada saat itu masyarakat setempat sulit mendapatkan air bersih untuk kebutuhan sehari-hari. Masyarakat kalau tidak mengambil dari bawah -karena desa pancur terletak di atas- maka mereka mengambil air (ngangsu) memakai ember dengan berjalan kaki sejauh $1 \mathrm{~km}$. BPPM kemudian mengembangkan program di sana bagaimana supaya masyarakat setempat bisa memperoleh air dengan mudah tanpa harus membeli dari daerah bawah, berjalan kaki (ngangsu) sejauh $1 \mathrm{~km}$, atau melakukan penggalian sumur yang justru banyak yang gagal. Maka Kiai Sahal melalui BPPM kemudian membuat saluran air yang dilihat dari sisi ekologis- ramah lingkungan, memperkecil pemakaian bahan-bahan material mahal dan tidak aman secara ekologis diganti dengan bahan yang bisa diperoleh masyarakat dari alam yakni melalui bambu yang diawetkan dan dilubangi. Karena air dari gunung terkadang kotor atau keruh maka dibuatlah alat saringan alami dari batu kapur, pasir, dan tanah sehingga masyarakat dapat memperoleh air dalam kondisi yang bersih. Pesantren saat itu hanya mengenalkan teknologi tepat gunanya, untuk pembuatannya mengajak masyarakat membuatnya sendiri secara gotong royong. Dengan demikian masyarakat dapat memperoleh air bersih melalui kerjasama masyarakat itu sendiri dengan bantuan BPPM.

Kiai Sahal merupakan orang pertama yang menggagas bahwa bukan tidak mungkin suatu saat kajen akan mengalami banjir, hal itu disampaikan beliau pada tahun 1987. Karena Kiai Sahal melihat pengambilan air yang berlebihan untuk industtri tepung, penebangan pohon di sekitar Ngemplak mulai besar, serta dampak perilaku masyarakat yang membuang semua liKiairumah tangga ke sungai. Dan hal itu terbukti saat ini, di mana kajen sudah mengalami banjir ketika terjadi hujan lebat sehingga jelas prediksi Kiai Sahal akan bencana banjir di Kajen. Begitu luar biasanya pemikiran Kiai Sahal, visioner, berpandangan jauh ke depan, melampaui apa yang dipikirkan masyarakat umum. Selain itu, integrasi pendidikan eko-religius dalam berbagai bidang kehidupan merupakan langkah yang cerdas dan tepat sasaran. Kiai Sahal merupakan sosok ulama yang tidak banyak bicara dalam mengatasi masalah sosial tetapi langsung kerja berlandaskan ajaran agama Islam untuk mengatasi 
berbagai persoalan yang dihadapi masyarakat.Pendidikan eko-religius menjadi salah satu gagasan Fiqh Sosial khas Kiai Sahal yang spesifik dalam masalah lingkungan hidup. Berangkat dari pemahaman bahwa tanpa lingkungan yang sehat, aman, nyaman, bersih, dan lestari, maka akan sulit menjamin tercapainya maqhasid al-syariah yakni keselamatan agama, jiwa, akal, keturunan, dan harta. Kesejahteraan sosial menyangkut seluruh aspek kehidupan manusia akan dapat tercapai dengan adanya keseimbangan dan kelestarian lingkungan hidup.

\section{Simpulan}

Gagasan fiqh sosial KH. MA. Sahal Mahfudh merupakan pemikiran yang visioner dalam membumikan ajaran agama Islam. Gagasan ini mampu menjawab problematika umat sesuai konteksnya masing-masing. Salah satu problem yang dihadapi umat saat ini adalah kerusakan lingkungan hidup yang semakin parah. Kiai Sahal, melalui tulisan dan gerakan sosialnya ternyata sudah memperhatikan permasalahan lingkungan hidup ini. Melalui fiqh sosial, Kiai Sahal telah mewacanakan konsep pendidikan lingkungan hidup (ekologis) dengan menjadikan ajaran agama Islam (religiusitas) sebagai landasan utamanya. Pemaparan hasil penelitian tentang konsep pendidikan eko-religius dapat disimpulkanbahwa secara eksplisit Kiai Sahal tidak menggunakan istilah Pendidikan Eko-religius dalam menjelaskan konsep tentang pendidikan lingkungan hidup. Namun pembinaan lingkungan hidup yang diwacanakan merupakan interpretasi dari ajaran agama Islam yang bersumber dari al-Quran, al-Hadits, dan ijtihad para ulama. Maka peneliti menggunakan istilah pendidikan eko-religius dalam menunjukkan pemikiran Kiai Sahal tentang lingkungan. Pendidikan eko-religius secara sederhana dapat disimpulkan sebagai pendidikan tentang berbagai masalah lingkungan hidup dengan menjadikan ajaran Islam sebagai landasannya. Beberapa konsep pendidikan ekoreligius Kiai Sahal antara lain (a)Tujuan pendidikan eko-religius Kiai Sahal berangkat dari tujuan akhir manusia, yaitu mencapai kebahagiaan dunia akhirat (sa'adatuddarain). Untuk mencapai tujuan tersebut, seseorang harus menjadi insan yang shalih (paling baik perilakunya) dan akram (paling bertaqwa). Pendidikan eko-religius Kiai Sahal menjelaskan bahwa manusia yang akram adalah manusia yang paling bertaqwa kepada Allah SWT. Taqwa ini kemudian dimanivestasikan dalam diri manusia shalih yaitu mereka yang mampu mewarisi bumi ini dalam arti luas mengelola, menyeimbangkan, dan melestarikan alam. Dengan demikian maka bumi akan terhindar dari kerusakan yang sebagian besar terjadi karena ulah tangan manusia; (b) Pendekatan dalam pendidikan eko-religius ini dapat dilakukan melalui tiga cara, yaitu pendekatan proyek, pendekatan motivasi, dan pendekatan kolaboratif antara proyek dengan motivasi. Pendekatan proyek lebih menitikberatkan pada 
proyek atau kegiatan sebagai medianya. Sementara pendekatan motivasi dilakukan melalui proses pembelajaran untuk menanamkan dan menumbuhkan karakter, sikap serta perilaku peduli lingkungan. Sedangkan pendekatan kolaboratif berarti memadukan antara proyek dengan motivasi, yakni proyek yang diawali dengan pembelajaran terlebih dahulu, atau sebaliknya, pembelajaran dengan diakhiri pembuatan proyek; (c) Evaluasi pendidikan ekoreligius, dilakukan dengan menjadikan penilaian masyarakat dari apa yang telah dilakukan seseorang di kehidupan sosialnya sebagai indikatornya. Evaluasi pendidikan eko-religius bukan lagi menggunakan tes akademik, melainkan memakai standar penilaian kinerja. Semakin banyak yang dilakukan dalam upaya melestarikan lingkungan hidup, semakin menunjukkan keberhasilan pendidikan eko-religius. Diseminasi Pendidikan Eko-religius Kiai Sahal dilakukan dalam berbagai bidang kehidupan terintegrasi dengan pemikiran dan kerja sosial Kiai Sahal. Beberapa bidang yang menjadi lahan diseminasi pendidikan eko-religius adalah pendidikan, ekonomi, dan sosial kemasyarakatan. Dalam bidang pendidikan, konsep ini diintegrasikan dalam berbagai mata pelajaran baik di pesantren maupun lembaga lain yang dipimpin Kiai Sahal. Di bidang ekonomi, Kiai Sahal mengajak pengusaha mengolah liKiaihasil kegiatan ekonomi sebelum dibuang supaya tidak mencemari lingkungan. Untuk bidang sosial, Kiai Sahal mengutamakan pemakaian teknologi ramah lingkungan dalam setiap kegiatan sosial.

\section{Daftar Pustaka}

Agus, Cahyono. (2016). Darurat Lingkungan, dalam Kedaulatan Rakyat, edisi 10 Februari Arikunto, Suharsimi. (2002). Prosedur Penelitian - Suatu Pendekatan Praktek. Cet. XII. Edisi Revisi V. Jakarta: PT. Rineka Cipta

Darmaningtyas. (2007). Pendidikan Rusak-rusakan. cet. II. Yogyakarta: LKiS

Furchan, Arief. dan Agus Maimun. (2005). Studi Tokoh; Metode Penelitian Tokoh. Yogyakarta: Pustaka Pelajar

Goleman, Daniel. (2010). Ecological Intelligences. Jakarta: PT. Gramedia

Jabrohim.(2003). Tahajjut Cinta. Yogyakarta: Pustaka Pelajar

Karim, Abdul. (2012). Manajemen Pendidikan Lingkungan Hidup Berbasis Partisipasi. Yogyakarta: Pustaka Ifada

Kattsoff, Louis O. (2004). Pengantar Filsafat. judul asli Elements of Philosophy. alih bahasa: Soejono Soemargono. Yogyakarta: Tiara Wacana

Keraf, A. Sony. (2006). Etika Lingkungan. cet. III. Jakarta: Kompas

M. Mushthafa. (2013). Sekolah dalam Himputan Google dan Bimbel. Yogyakarta: LKiS

Mahfudh, Sahal. (2012). Nuansa Fiqh Sosial. cet. 11. Yogyakata: LKiS

Muhadjir, Noeng. (2002). Metodologi Penelititan Kualitatif. edisi IV. cet. II. Yogyakarta: Rake Sarasin

Notoatmodjo, Soekidjo. (2007). Kesehatan Masyarakat; Ilmu dan Seni. Jakarta: Rineka Cipta 
Rahardjo, S., Dina, L., dan Suyono. (2006). Pengendalian Dampak Lingkungan. Surabaya: Penerbit Airlangga

Rahmat, Jalaluddin. (2001). Psikologi Agama. Jakarta: Raja Grafindo Persada

Said Nahdi, Maizer, dan Aziz Ghufron. (2006). "Etika Lingkungan dalam Perspektif Yusuf al-Qardawy". Jurnal Al-Jamiah, Vol. 44, No. 1

Shihab, M. Quraish. (2010). Tafsir Al-Mishbah. Jakarta: Lentera Hati

Sugiyono. (2009). Metode Penelitian Kualitatif, Kuantitatif, dan R\&D. Bandung: Alfabeta

Undang-undang Nomor 32 tahun 2009 tentang Perlindungan dan Pengelolaan Lingkungan Hidup

Harian Kompas edisi $16 \quad-\quad 17 \quad$ Februari tahun 2016

http://badanbahasa.kemdikbud.go.id/kbbi/index.php

http://www.antaranews.com/berita 